\title{
Analysis of Furniture Selling Places in Croatia, Slovenia and Slovakia
}

\section{Analiza prodajnih mjesta namještaja u Hrvatskoj, Sloveniji i Slovačkoj}

\author{
Original scientific paper • Izvorni znanstveni rad \\ Received-prispjelo: 23. 12. 2015. \\ Accepted-prihvaćeno: 5. 5. 2016. \\ UDK: $630 * 079$ \\ doi:10.5552/drind.2016.1545
}

\begin{abstract}
Nowadays, furniture retail sale is a very competitive area and besides large and well-known global brands, a high share of the overall market consists of independent retail shops. The owners and sellers of furniture are daily faced with the increasing requirements of the ever more demanding market, to which they must constantly and repeatedly adjust. The choice of furniture stores regarding to some of selling place attributes could affect customer's final decision about furniture purchase; however, there is little information about the relationship between furniture selling places attributes. In this study, the basic information is given regarding the selected furniture selling place attributes (size of selling area, number of salespersons, storage area, and number of suppliers) in Slovenia, Slovakia, and Croatia.
\end{abstract}

Keywords: furniture, selling place, analysis, Croatia, Slovenia, Slovakia

SAŽETAK • Danas uz velike trgovačke lance poznatih svjetskih brandova namještaja $i$ mala nezavisna prodajna mjesta namještaja imaju važnu ulogu na cjelokupnom tržištu namještaja. Vlasnici i prodavači namještaja svakodnevno se pokušavaju prilagoditi sve zahtjevnijim željama i potrebama svojih kupaca. Nadalje, pojedina obilježja prodajnih mjesta namještaja mogu utjecati na kupčevu konačnu odluku o kupnji namještaja, što je glavni predmet istraživanja brojnih studija i radova. Nasuprot tome, vrlo je malo radova u kojima je istraživan međusobni utjecaj obilježja prodajnog mjesta namještaja, pa je cilj ovog rada bio istražiti neke od njih (veličinu prodajnog prostora, broj prodavača, veličinu skladišnog prostora i broj dobavljača), utvrditi njihov međusobni utjecaj te ustanoviti postoji li razlika među odabranim obilježjima prodajnih mjesta namještaja u Hrvatskoj, Sloveniji $i$ Slovačkoj.

Ključne riječi: namještaj, prodajna mjesta, analiza, Hrvatska, Slovenija, Slovačka

\footnotetext{
${ }^{1}$ Author is assistant at Faculty of Forestry, University of Zagreb, Zagreb, Croatia. ${ }^{2}$ Author is professor at Faculty of Forestry, University of Zagreb, Zagreb, Croatia. ${ }^{3}$ Author is professor at Technical University in Zvolen, Faculty of Wood Sciences and Technology, Zvolen, Slovakia. ${ }^{4}$ Author is assistant at Faculty of Forestry University of Zagreb, Zagreb, Croatia. ${ }^{5}$ Author is director of the company Pilana-Mrkopalj, Mrkopalj, Croatia. ${ }^{6}$ Author is professor at University of Ljubljana, Biotechnical Faculty, Ljubljana, Slovenia

Autorica je asistentica na Šumarskom fakultetu Sveučilišta u Zagrebu, Zagreb, Hrvatska. ${ }^{2}$ Autor je profesor na Šumarskom fakultetu Sveučilišta u Zagrebu, Zagreb, Hrvatska. ${ }^{3}$ Autor je profesor na Tehničkom sveučilištu u Zvolenu, Fakultet drvnih znanosti, Zvolen, Slovačka. ${ }^{4} \mathrm{Au}-$ torica je asistentica na Šumarskom fakultetu Sveučilišta u Zagrebu, Zagreb, Hrvatska. ${ }^{5}$ Autorica je direktorica tvrtke Pilana-Mrkopalj, Mrkopalj, Hrvatska. ${ }^{6}$ Autor je profesor na Sveučilištu u Ljubljani, Biotehnički fakultet, Ljubljana, Slovenija.
} 


\section{INTRODUCTION}

\section{UVOD}

Besides large and well-known global brands, a significant share of the overall market consists of independent retail shops (Yitong, 2007). Consumers do not only differ by age, gender and occupation, but also by their interests and preferences. Diversity does not exist only within consumers, but also within sellers. Sellers foreground task is to understand, monitor and meet customer needs and desires - regardless of who they are, what they want, or where they live (Schiffman and Kanuk, 2004; Kotler et al., 2006; Kim and Mauborgne, 2007). In the past decade, the process of transition from a centrally planned to a market economy has brought structural economic changes to Central and Eastern European countries, to which countries like Slovenia, Slovakia and Croatia belong to, and particularly so to wood and furniture sector of these countries (Kaputa el al., 2016; Pirc et al., 2010; Kitek Kuzman et al., 2012). On the other hand, today these countries are also a part of European Union, worldly the largest region for furniture consumption and manufacturing in which retailing has been recognized and adopted to new conditions within a very short period of time. However, considering sustainable growth of furniture manufacturing, it is still necessary to encourage investment, and ensure access to global markets creating competitive conditions (Družić and Basarac Sertić, 2015). Among the countries that joined the EU, originally established in 2004, Slovakia valued furniture consumption at 646 million Euros in 2012, while Slovenia reached the amount of 284 million Euros (Centre for European Policy Studies, 2014). In July, 2013, Croatia became the youngest member of the EU with furniture consumption valued at 432 million Euros (Financial Agency 2014). According to the European Commission (2013), European furniture sale was valued at approximately 50 billion EUR in 2011, decreasing by $2.1 \%$ if compared to 2010 . Consumer spending on furniture is forecast to increase at a faster pace than in the past few years; global furniture sales grew by 5.5 $\%$ in 2014 (French, 2015). The market is still dominated by Germany, Italy, the UK and France, which accounted for over $69 \%$ of EU27 sales in 2011 . There are many elements that make up a store's image by considering the type of customers - sales personnel is one of them. According to Jones et al. (2005), among other elements, a customer satisfaction increases in relation to salesperson speed of response; a customer also expects to be served quickly and completely. Waiting for service is very often the first interaction between customer and service process (Davis and Heineke, 1998) and many service companies and stores worry about the waiting time, because the customer waiting time is considered as having a negative influence on consumer service perception (Bielen and Demoulin, 2007). The customer's purchasing power is the result of mixed issues. According to the Centre for European Policy Studies (2014), among other elements, these issues also include warehousing and sale personnel assistance in the process of sale. The availability of information offers the consumers the possibility of choice, while the purchase has become unbelievably easy and fast, which has made the selling place a very important point in the final choice of the product (Oblak, 1992). Today, big furniture stores are becoming more popular than before (Dong and Zhao, 2012) and furniture retail sale has become a very competitive area.

\subsection{Research objectives}

1.1. Ciljevi istraživanja

In 2012, the share of furniture consumption of these three countries, Slovenia, Slovakia, and Croatia, in the total share of EU furniture consumption was between 0.4 and $0.8 \%$. No significant difference between the shares of Croatian, Slovenian, and Slovakian furniture consumption in total share of EU furniture consumptions was found $\left(\chi^{2}=0.18, d f=2, p=0.92\right)$.

The choice of furniture stores regarding to some of selling place attributes could affect customer's final decision about furniture purchase. However, there is little information about the relationship between furniture selling place attributes. In an effort to compare and analyse furniture selling places, the following research goals were set:

- to determine the basic information on some furniture selling place attributes in Slovakia, Slovenia, and Croatia;

- to establish correlations between the size of furniture selling area and number of sellers in the selling places, storage area in the selling places and number of suppliers in the selling places in Croatia, Slovenia and Slovakia.

- to determinate the differences in attributes between furniture selling places in Croatia, Slovenia and Slovakia.

\section{MATHERIALS AND METHODS 2. MATERIJALI I METODE}

A questionnaire was used for surveying respondents (furniture selling places) for this study. This approach was selected because it provides the possibility of collecting data over a wide geographic area and lowcost data conversion (Zahs and Baker, 2007). The questionnaire consisted of the following items: general information on selling place (name and address), number of furniture suppliers, size of selling area (in $\mathrm{m}^{2}$ ), size of storage area (in $\mathrm{m}^{2}$ ), and number of sellers. The sample frame was a census of 400 furniture selling places in Slovakia, Slovenia, and Croatia. The list of furniture selling places was taken from the data base of the Croatian, Slovakian, and Slovenian Chambers of Commerce. A telephone survey, based on procedures recommended by Dillman (2000), was used in this study. In Croatia, the total number of usable surveys received was 258 with adjusted response rate of $64 \%$. In Slovenia, the total number of usable surveys received was 85 with adjusted response rate of $21 \%$, while in Slovakia, the total number of usable surveys received was 92 with adjusted response rate of $23 \%$. 
The adjusted response rate was calculated using the following expression: Adjusting Response Rate = [Usable Surveys /Total sample - (Undeliverable + Unusable)]*100\%. Questionnaire data was entered into a Microsoft Excel data base. Statistical analysis and results interpretation were carried out using the statistical software Statistica 10. The research was conducted in 2011. Regression analysis was used to determine the correlation between the size of sales area and number of suppliers, size of storage space and number of sellers in Croatia, Slovenia and Slovakia. In order to determine whether there were significant differences in attributes between furniture selling places in Croatia, Slovenia and Slovakia, $\chi^{2}$-test was used.

\section{RESULTS}

\section{REZULTATI}

\subsection{Characteristics of furniture selling places in} Croatia, Slovenia and Slovakia

3.1. Obilježja prodajnih mjesta namještaja u Hrvatskoj, Sloveniji i Slovačkoj

Comparing the three surveyed countries (Croatia, Slovenia, and Slovakia), as shown in Tab. 1, it can be seen that the largest furniture selling places were located in Slovenia (the average size of furniture selling place amounted to $498.20 \mathrm{~m}^{2}$ ). In Croatia, the average size of furniture selling area was $405.92 \mathrm{~m}^{2}$ while in Slovakia, the average size of furniture selling places was $345.40 \mathrm{~m}^{2}$. As shown in Figure 1 and Figure 2, regarding the average number of furniture suppliers and the average size of the storage area of furniture showrooms, Slovenian furniture showrooms were noted as selling places having the largest number of furniture suppliers (average 20.07) and the largest size of the storage area $\left(361.9 \mathrm{~m}^{2}\right)$. In Croatia, the average number of furniture suppliers was 11.1 and the average size of the storage area amounted to $257.2 \mathrm{~m}^{2}$. In Slovakia, the average number of suppliers was 13.5 and the average size of the storage area was $143.3 \mathrm{~m}^{2}$. Regarding the number of people employed in furniture selling places, as shown in Table 1, the largest number of people were employed in Slovakian showrooms (3.60 persons on average), followed by Croatia (3.36 on average), and Slovenia (3.28 persons on average) (Fig. 1 and Fig. 2).

\subsubsection{Croatia \\ 3.1.1. Hrvatska}

In Croatia, according to the results, a simple linear regression model of correlation regarding the size of furniture selling area and the number of furniture suppliers was: $y=346.03+5.391 \cdot x$. The correlation between the selling area and the number of furniture suppliers is shown using a regression coefficient of determination $\left(R^{2}=0.025\right)$. The above regression coefficient of determination indicated that the model of linear regression explaining these two variables is not representative, meaning that the size of furniture selling place in Croatia explains only $2.5 \%$ of the number of furniture suppliers. The adjusted coefficient of determination was $2.2 \%$.

Furthermore, observing the size of the selling area and the size of the storage area, a medium inten-

Table 1 Descriptive statistics of some characteristics of furniture selling places

Tablica 1. Deskriptivna statistika obilježja prodajnih mjesta namještaja

\begin{tabular}{|c|c|c|c|c|c|c|c|c|c|}
\hline \multirow[t]{2}{*}{$\begin{array}{l}\text { Country } \\
\text { Država }\end{array}$} & \multirow[t]{2}{*}{$N$} & \multicolumn{2}{|c|}{$\begin{array}{c}\text { Size of selling area, } \mathbf{m}^{2} \\
\text { Veličina prodajnog } \\
\text { prosotra, } \mathrm{m}^{2}\end{array}$} & \multicolumn{2}{|c|}{$\begin{array}{c}\text { Number of } \\
\text { suppliers } \\
\text { Broj dobavljača } \\
\end{array}$} & \multicolumn{2}{|c|}{$\begin{array}{l}\text { Size of storage area } \\
\text { Veličina skladišnog } \\
\text { prostora, } \mathrm{m}^{2}\end{array}$} & \multicolumn{2}{|c|}{$\begin{array}{c}\text { Number of } \\
\text { sellers } \\
\text { Broj prodavača }\end{array}$} \\
\hline & & Mean & St. Dev. & Mean & St. Dev. & Mean & St. Dev. & Mean & St. Dev. \\
\hline Croatia / Hrvatska & 258 & 405.92 & 463.27 & 11.11 & 13.71 & 257.19 & 2.55 & 3.36 & 2.55 \\
\hline Slovenia / Slovenija & 85 & 498.20 & 453.48 & 20.07 & 20.73 & 361.93 & 629.16 & 3.28 & 1.58 \\
\hline Slovakia / Slovačka & 92 & 345.43 & 525.70 & 13.51 & 16.26 & 143.26 & 246.80 & 3.60 & 3.91 \\
\hline
\end{tabular}
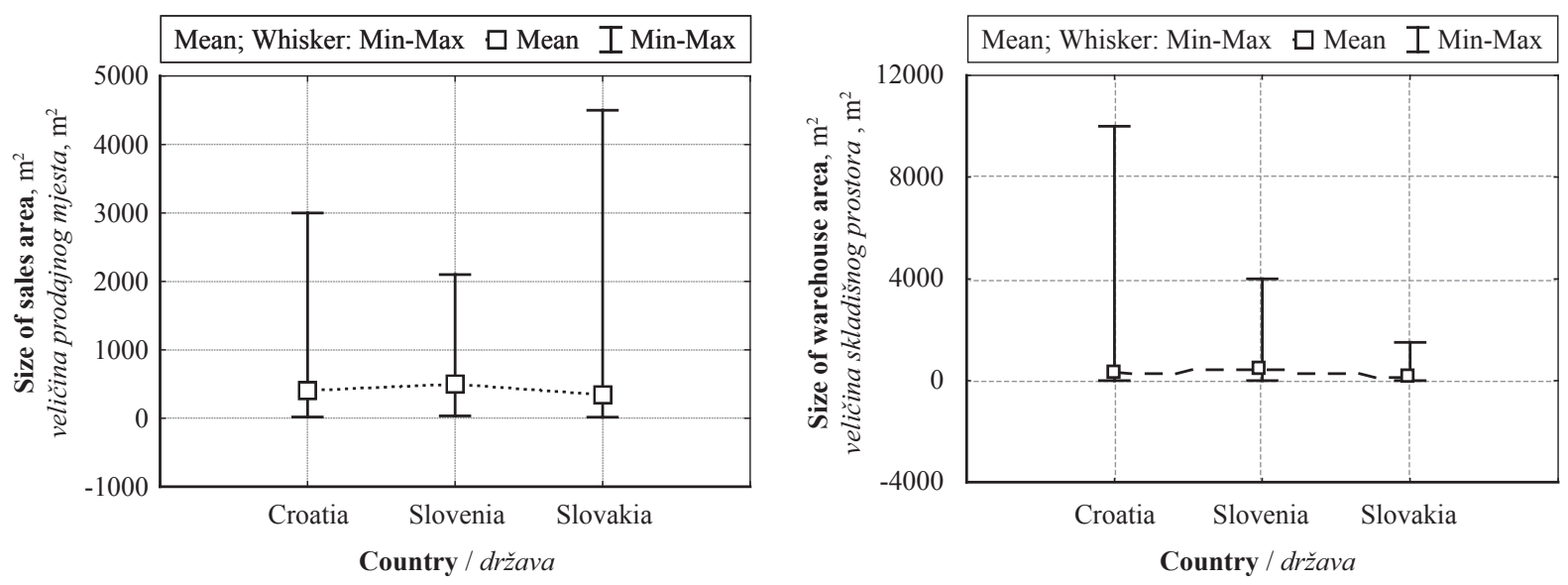

Figure 1 Size of selling area and size of storage area of furniture selling places in analyzed countries

Slika 1. Veličine prodajnih i skladišnih prostora prodajnih mjesta namještaja u analiziranim zemljama 

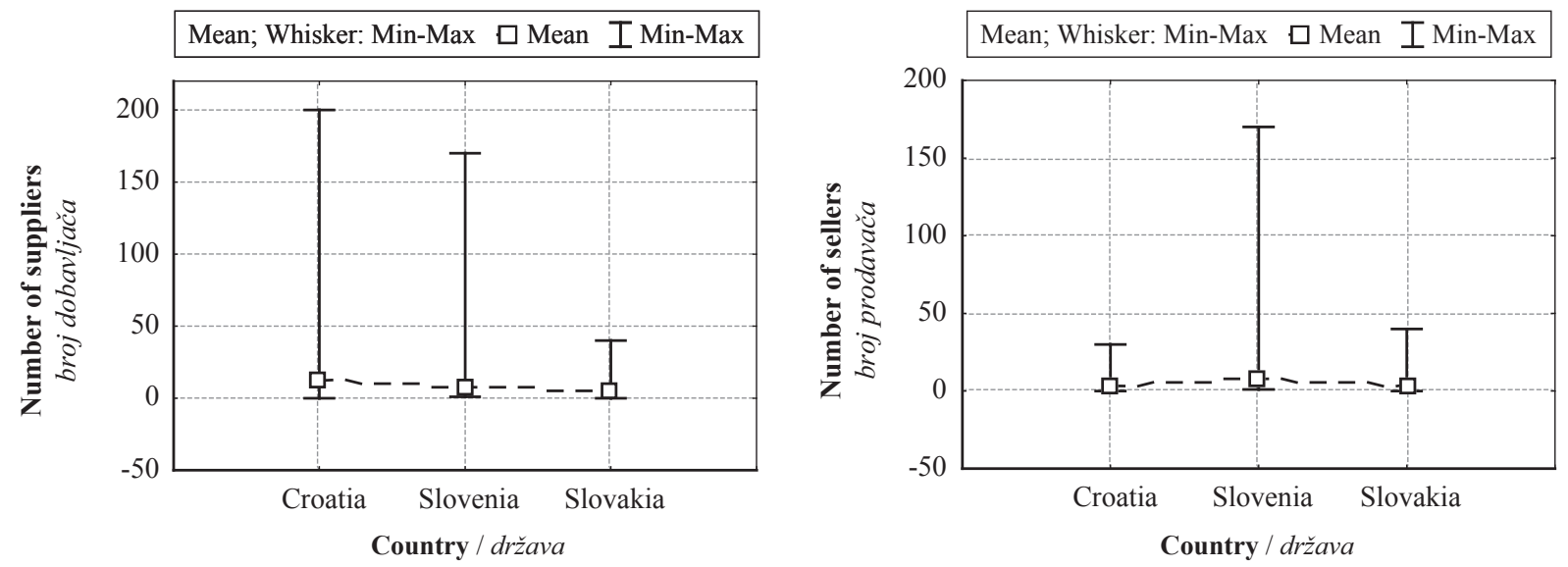

Figure 2 Number of suppliers and number of sellers of furniture selling places in analyzed countries Slika 2. Broj dobavljača i broj prodavača na prodajnim mjestima namještaja u analiziranim zemljama

sity correlation was established $\left(R^{2}=0.362\right)$. The coefficient of correlation was positive (i.e. the size of the storage area is enhanced with the size of furniture selling place $)$ and statistically significant $(r=0.602$; $p=0.0001)$.

Similarly, regarding the size of the furniture selling area and the number of furniture sellers, a medium intensity correlation was established. The coefficient of correlation was positive and statistically significant $(r=0.633 ; p=0.0001)$. Coefficient of determination $\left(R^{2}\right)$ was 0.401 (Tab. 2).

\subsubsection{Slovenia}

\subsubsection{Slovenija}

In Slovenia, week dependence was established between the size of furniture selling area and the number of sellers, the number of furniture suppliers and the size of the storage area. Regression coefficient of determination $\left(R^{2}\right)$ between the size of the selling area and the number of sellers was 0.032 .

The coefficient of determination of regression between the selling area and the number of suppliers and between the selling area and the storage area was the same (number of suppliers: $R^{2}=0.118$; size of storage area: $\left.R^{2}=0.118\right)$.

A simple linear regression model of correlation between the size of furniture selling area and: (a) number of sellers, (b) number of furniture suppliers, and (c) size of the storage area was as follows: (a) $y=330.333$ $+51.142 \cdot x$. (b) $y=347.248+7.522 \cdot x$, (c) $y=408.717$ $+0.247 \cdot x$. The coefficients of correlation regarding the size of the selling area and number of furniture suppliers $(r=0.344 ; p=0.0013)$ and size of the storage area $(r=0.343 ; p=0.0013)$ were statistically significant. On the other hand, the coefficients of correlation regarding the size of the selling area and number of sellers were not statistically significant $(r=0.178 ; p=$ 0.0103 ) (Tab 2.)

\subsubsection{Slovakia}

\subsubsection{Slovačka}

In Slovakia, using a simple regression analysis, a medium intensity correlation was established between the size of furniture selling area and storage area
$\left(R^{2}=0.330 ;\right.$ simple regression model: $y=$ $170.111+1.224 \cdot x)$ and between the size of furniture selling area and the number of sellers $\left(R^{2}=0.399\right.$; simple regression model: $y=39.376+85.068 \cdot x)$. Furthermore, a weak intensity correlation was established between the size of the selling area and the number of furniture suppliers. The correlation is expressed using the regression coefficient of determination $\left(R^{2}\right)$ that amounted to 0.012 (i.e. the size of furniture sales area explains only $1.2 \%$ of the number of furniture suppliers).

Within all three analyzed countries (Croatia, Slovenia, and Slovakia), the results of a simple regression analysis between the variable "furniture selling area" and variables: size of storage area, number of furniture suppliers, number of sellers showed a weak correlation or a medium intensity correlation. In all observed comparisons, coefficients of correlations were positive at $\alpha$ $=0.05$ significance level and statistically significant (ex. Slovakia: size of selling area and number of suppliers) (Tab. 2).

Chi-square test was used to determinate differences within the size of furniture selling area, storage area, number of furniture suppliers, and number of sellers in Croatia, Slovenia and Slovakia. The null hypothesis was tested at $\alpha=0.05$ significance level. The size of the storage area was not found to be significant at $\alpha=0.05$ significance level between Croatia, Slovenia, and Slovakia $\left(\chi^{2}=21.51 ; d f=16 ; p=0.160\right)$. On the other hand, the size of the selling area $\left(\chi^{2}=18.28, d f=\right.$ $8, p=0.019)$, number of sellers $\left(\chi^{2}=16.44, d f=8, p=\right.$ $0.036)$, and the number of suppliers $\left(\chi^{2}=34.37, d f=\right.$ $10, p \leq 0.001)$ were found to be significant at $\alpha=0.05$ significance level (Fig. 3).

\section{DISCUSSION AND CONCLUSIONS 4. RASPRAVA I ZAKLJUČAK}

In the current economic context, future consumers' choice of whether to save money or to spend it depends on their overall perception and expectations, which can be asserted by the Eurostat consumer confidence indicator that showed a negative balance with respect to spending money on major purchases, which includes furniture. In this study, the basic information 
Table 2 Correlations of size of sales area and size of warehouse area, number of suppliers and number of sellers in analyzed countries

Tablica 2. Korelacije veličine prodajnog i skladišnog prostora, broja dobaljača i broja prodavača u analiziranim zemljama

\begin{tabular}{|c|c|c|c|c|c|}
\hline \multirow{4}{*}{$\begin{array}{l}\text { Size of selling area in Croatia, } \mathrm{m}^{2} \\
\text { Veličina prodajnog prostora } u \\
\text { Hrvatskoj, } \mathrm{m}^{2}\end{array}$} & & $r$ & $R^{2}$ & $\operatorname{Adj} R^{2}$ & $p$ \\
\hline & Number of suppliers / Broj dobavljača & 0.160 & 0.025 & 0.022 & 0.0102 \\
\hline & Size of storage area, $\mathrm{m}^{2} /$ Veličina skladišnog prostora $\mathrm{m}^{2}$ & 0.602 & 0.362 & 0.360 & 0.0001 \\
\hline & Number of sellers / Broj prodavača & 0.633 & 0.401 & 0.399 & 0.0001 \\
\hline \multirow{3}{*}{$\begin{array}{l}\text { Size of selling area in Slovenia, } \mathrm{m}^{2} \\
\text { Veličina prodajnog prostora } u \\
\text { Sloveniji, } \mathrm{m}^{2}\end{array}$} & Number of suppliers / Broj dobavljača & 0.344 & 0.118 & 0.108 & 0.0013 \\
\hline & Size of storage area, $\mathrm{m}^{2} /$ Veličina skladišnog prostora, $\mathrm{m}^{2}$ & 0.343 & 0.118 & 0.107 & 0.0013 \\
\hline & Number of sellers / Broj prodavača & 0.178 & 0.032 & 0.020 & 0.0103 \\
\hline \multirow{3}{*}{$\begin{array}{l}\text { Size of selling area in Slovakia, } \mathrm{m}^{2} \\
\text { Veličina prodajnog prostora } u \\
\text { Slovačkoj, } \mathrm{m}^{2}\end{array}$} & Number of suppliers / Broj dobavljača & 0.109 & 0.012 & 0.001 & 0.3013 \\
\hline & Size of storage area, $\mathrm{m}^{2} /$ Veličina skladišnog prostora, $\mathrm{m}^{2}$ & 0.574 & 0.330 & 0.323 & 0.0001 \\
\hline & Number of sellers / Broj prodavača & 0.632 & 0.399 & 0.393 & 0.0001 \\
\hline
\end{tabular}

Legend/ Legenda: $r$ - correlation coefficient / koeficijent korelacije; $R^{2}$ - coefficient regression of determination / koeficijent determinacije; Adj $R^{2}$ - determination coefficient adjusted / korigirani koeficijent determinacije; $p$ - level of significance / razina značajnosti.

was given on some furniture selling place attributes (size of selling area, number of sellers, storage area, and number of suppliers) in relatively new EU countries (Slovenia, Slovakia, and Croatia), and the test was determined for the correlations between the size of the selling area and other three sale place attributes (number of sale persons, storage area, and number of suppliers) in Slovenia, Slovakia, and Croatia. Additionally, the differences in three furniture selling place attributes between Croatian, Slovenian, and Slovakian furniture

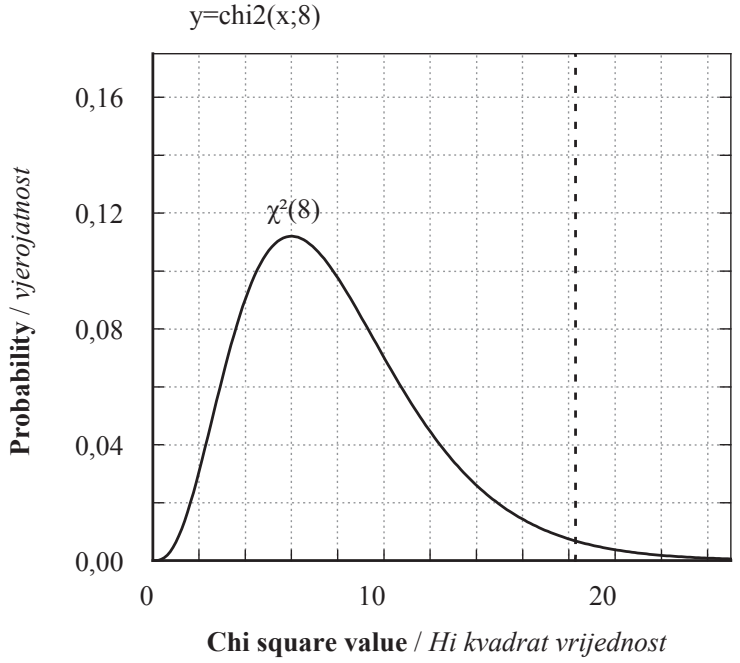

(a)

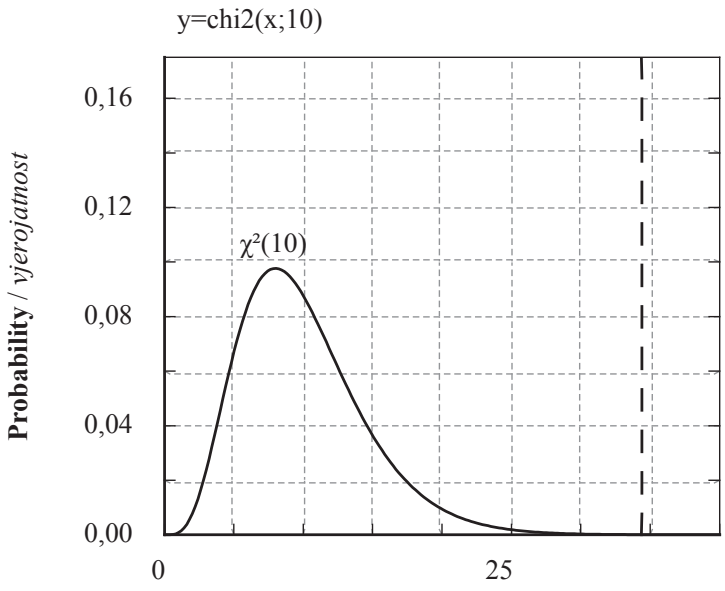

Chi square value / Hi kvadrat vrijednost

(c)

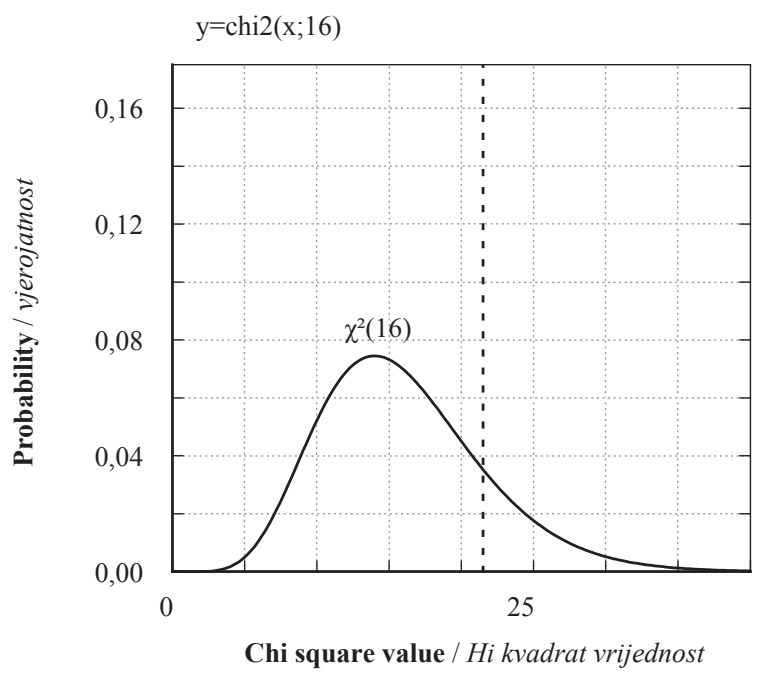

(b)

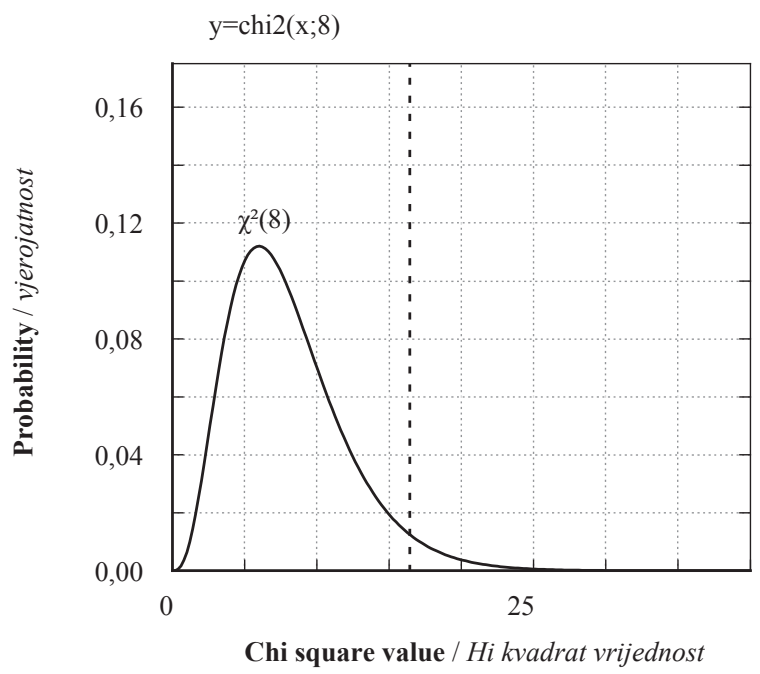

(d)

Figure $3 \chi^{2}$ distribution: (a) size of selling area; (b) size of storage area; (c) number of suppliers; (d) number of sellers Slika 3. $\chi^{2}$ distribucija: (a) veličina prodajnog prostora; (b) veličina skladišnog prostora; (c) broj dobavljača; (d) broj prodavača 
selling places were determined. In Croatia, a higher level of correlation was established between selling place attributes. One of possible reasons of higher correlation between the selling area and other selling place attributes could be that the Croatian market is still traditionally oriented, the process of transition from the traditional sales functions is still dominating, customers are more oriented to seller face-to-face contact and less to contemporary technology, like internet selling platforms, than in Slovakia and Slovenia. According to the Centre for European Policy Studies (2014), some EU countries, including Slovakia, Slovenia, and Croatia, index of furniture consumption per capita are below EU average, so the results of this study indicate a glaring need to probe further into furniture selling place attributes, because the attributes of selling place play an important role in customer decision process when buying wood furniture.

This study has limitations, because it is looking at a specific point in time without longitudinal data. Nevertheless, additional cross-national studies in the European Union could validate the findings presented in this work. Furthermore, the findings of this research can only be generalized for surveying furniture selling places in Croatia, Slovenia, and Slovakia, which presents an important limitation. We suggest that future research should include additional cross-national studies in the EU for well-established and new members, as well as longitudinal studies to see how these furniture selling place attributes change over time.

\section{REFERENCES}

5. LITERATURA

1. Bielen, F.; Demoulin, N., 2007: Waiting time influence on the satisfaction-loyalty relationship in service, Managing Service Quality, 17 (2): 174-193. http://dx.doi. org/10.1108/09604520710735182.

2. Davis, M. M.; Heineke, J., 1998: How disconfirmation, perception and actual waiting times impact customer satisfaction, International Journal of Service Industry Management, 9 (1): 64-73. http://dx.doi.org/10.1108/09564239810199950.

3. Dillman, D. A., 2000: Mail and Internet Surveys - the Tailored Design Method. John Wiley \& Sons, Inc. New York, USA.

4. Dong, H.; Zhao, L., 2012: A study of teh Evacuation of Large Furniture Stores, Journal of Chinese People's Armed Police Force Academy. http://en.cnki.com.cn/Article_en/CJFDTOTAL-WUJI201210019.htm (Acessed: September 1st, 2015).

5. Družić, G.; Basarac Sertić, M., 2015: A roadmap of actions aiming at ensuring furniture industry production growth: panel analysis. Economic Research-Ekonomska Istraživanja, 28 (1): 572-582.

http://dx.doi.org/10.1080/1331677X.2015.1083458.
6. French, D., 2015: Furniture Today. Available at: www. furnituretoday.com.

7. Kaputa, V.; Paluš, H.; Vlosky, R., 2016: Barriers for wood processing companies to enter foreign markets: a case study in Slovakia. European Journal of Wood and Wood Products, 74 (1): 109-122. http://dx.doi.org/10.1007/s00107-015-0954-5.

8. Kim, W. C.; Mauborgne, R., 2007: Blue ocean strategy. Poslovni dnevnik and Masmedia, Zagreb, Croatia.

9. Kotler, P.; Wong, V.; Saunders, J.; Armstrong, G., 2006: Principles of marketing. 4th edition, Mate, Zagreb, Croatia.

10. Kitek Kuzman, M.; Motik, D.; Bičanić, K.; Vlosky, R.; Oblak, L., 2012: A comparative analysis of consumer attitudes on the use of wood products in Slovenia and Croatia. Drvna industrija, 63 (2): 71-79. http://dx.doi.org/10.5552/drind.2012.1129.

11. Oblak, L., 1992: Competitiveness ranking of furniture stores in Ljubljana, Diploma thesis. Biotechnical Faculty, Department of Wood Science, Ljubljana, Slovenia.

12. Pirc, A.; Motik, D.; Moro, M.; Posavec, S.; Kopljar, A., 2010: Analiza pokazatelja stanja na tržištu drvnih proizvoda Republike Hrvatske. Drvna industrija, 61 (4): 229238.

13. Schiffman, L. G.; Kanuk, L. L., 2004: Consumer behaviour, Mate, Zagreb, Croatia.

14. Sheth, J. N.; Sharma, A., 2008: The impact of the product to service shift in industrial markets and the evolution of the sales organization. Industrial Marketing Management, 37 (3): 260-269. http://dx.doi.org/10.1016/j.indmarman.2007.07.010.

15. Yihong, L., 2007: Ikea success in Chinese furniture, Jyväskylän Ammattikoreakoulu School of Business, October, 2007.

16. Zahs, D.; Baker, R., 2007: Telephone and Mail Surveys: Advantages and Disadvantages of Each. Market Strategies, Inc.

17. *** 2013: Revision of Eco label and Green Public Procurement criteria for the product group - Wooden Furniture. Available: Commission http://susproc.jrc.ec.europa. eu/furniture/ (Accessed on June 25th, 2015).

18. *** 2014: The EU Furniture market solution and a possible furniture products initiative, Centre for European Policy Studies, Final report, Brussels, 2014. https://www. ceps.eu/system/files/Final\%20report_en.pdf (Accessed September 12th, 2015).

\section{Corresponding address:}

\section{ANDREJA PIRC BARČIĆ, Ph.D.}

University of Zagreb

Faculty of Forestry

Svetošimunska 25

10000 Zagreb, CROATIA

e-mail: apirc@sumfak.hr 